\title{
THE EFFECTS OF SOCIAL MEDIA ADVERTISING AMONG ECO-TOURISTS IN MALAYSIA: AN EMPIRICAL STUDY ON MALAYSIAN ECOTOURISM
}

\author{
Mohammad Arije ULFY \\ International Islamic University Malaysia, Department of Business Administration, Kuala Lumpur, Malaysia, e-mail: md.arije@hotmail.com \\ Md Suliman HOSSIN* \\ University Kuala Lumpur, 4School of Business, Malaysia, e-mail: md.suliman@s.unikl.edu.my
}

\author{
Md Wasiul KARIM
}

International Islamic University Malaysia, Department of Business Administration, Kuala Lumpur, Malaysia, e-mail: wasiul45@gmail.com

\author{
Zohurul ANIS
}

University of Rajshahi, Department of Management Studies, Rajshahi, Bangladesh, e-mail: zohurul.anis@gmail.com

\begin{abstract}
Citation: Ulfy, M.A., Hossin, M.S. Karim, M.W., \& Anis, Z., \& (2021). THE EFFECTS OF SOCIAL MEDIA ADVERTISING AMONG ECO-TOURISTS IN MALAYSIA: AN EMPIRICAL STUDY ON MALAYSIAN ECOTOURISM. GeoJournal of Tourism and Geosites, 38(4), 997-1004. https://doi.org/10.30892/gtg.38402-736
\end{abstract}

\begin{abstract}
The focus of the study is to achieve the maximum advertising value on ecotourists using social media. In this area, the main objective of the "Technology Acceptance Model (TAM)" is to increase the present awareness of social media marketing. This topic is primarily concerned with exploring the context of social media advertisement with knowledge, service, and its behavioural intent to use social media ads within the unique environment of ecotourism in Malaysia. The approach of the study is to analyse a survey of 395 local Malaysian tourists in Klang Valley to test the "Technology Acceptance Model (TAM)". The empirical findings denote that social media advertisement in ecotourism has positive effects on "Perceived ease of use" and "Perceived usefulness," in terms of its 'Informativeness' and "Service Functionality." That, in effect, contributes to the behavioural purpose of using social media ecotourism advertisements. The discipline's findings indicate that advertising in social media in ecotourism needs to be utilized to provide a quick understanding. Also, the advertising is updated continuously to ensure reliable and appropriate sources to meet ecotourists' information requirements and the support of tourist product ratings. These traits should satisfy travellers, making them likely to revisit different ecotourism sights. These appearances should satisfy tourists and allow them to re-visit various ecotourist attractions.
\end{abstract}

Key words: ecotourism, Malaysia, PLS-SEM, social media advertising, TAM

$* \quad * \quad * \quad * \quad * \quad *$

\section{INTRODUCTION}

Ecotourism is a normative estimate of well-defined and obsessed by widespread head value concerning resident livings and tribute of natural and traditional environment (Thompson et al., 2018). Ecotourism is Malaysia's fastest-growing tourism subsector, as noted by the national government (Lian Chan and Baum, 2007). Marketers use social media platform from the client's maintenance to commercial advertising. Social media advertising, therefore use the social media platforms, frequency, and software to generate, interconnect, distribute, and trade services which are valuable to an organization and its sponsors (Tuten and Mintu-Wimsatt, 2018). In the past decade, the accelerating upswing of the Internet blessing with ICT has enhanced the reach of advertising sites (El-Haddadeh et al., 2012). As a result, the conventional digital marketing network used by corporations has now been transferred to social media (Lee and Hong, 2016).

Tourism is steadily advancing in ads in social media through substantial share capital in advertisement expenditures (Duffett, 2015). Ecotourism is shifting its interest to the global south, primarily due to the increasing comprehensive understanding of sustainable tourism and the number of environmental activists (Yusof et al., 2014). In the context of the related contemporary setting, ecotourism is usually interpreted as a form of tourism that promotes learning and appreciation of the natural environment in a way that promotes cultural and natural heritage (Weaver, 2001). Social media also plays a significant role in both the travel and leisure industries (Chung and Buhalis, 2008). Leung et al. (2013) propose the use of social media ads in ecotourism with its three-phase view (before, during, and after the trip) of the rational cycle of travelling layout. Publicity on social media also plays a vital role as a coordination tool in ecotourism activity and direction. Social networking ads will also allow ecotourism companies to analyse business-to-client interactions by offering consumer input on the company's potential offerings (Jonassen et al., 2003). Moreover, social media is regarded as cost-efficient when it comes to promoting and encouraging tour packages in comparison to traditional publicity (Roult et al., 2016). In addition, social media provides consistent data and helps deal and meet customers' demands at the same time (Leung et al., 2013). While literature examined social sites, advertising is increasingly becoming reliable; though some shortcomings could be identified. Firstly, sufficient advertising work in social media remains at an incremental level with several distinct events and incomplete results (Taylor et al., 2011; Duffett, 2015). Secondly, social networking is an "ever-

\footnotetext{
* Corresponding author
} 
evolving area," as described in the case of the on-line advertising sector for operations, which is in constant development (Zhang and Mao, 2016). This indicates that the imperialised awareness of advertisements in social media tends to evolve with the rise and expansion of the use of social media. Thirdly, the majority of research in social media advertising are not specifically focused on a hypothesis or relate to a certain model for testing (Hammock, 2015). Furthermore, explorations are indeed required depending on such discussions (Bolton et al., 2013), particularly with an increasing use of social media networks in various enterprise segments such as ecotourism (Odoom et al., 2017).

The initial objective of this research is to demonstrate how social media advertisements truly affect ecotourists in Malaysia. Although several pieces of research concentrated on recognising various components that affect social media user acceptance behaviour (Saxena and Khanna, 2013; Roult et al., 2016; Dao et al., 2014), researchers often use contextual methods depending on personal interests to build social media advertisement technologies. Some of them greatly emphasize the theoretical framework and other conceptual models that were suggested but are yet to be verified. Consequently, though particular researches have made an approximate investigation of social media advertising on ecotourists, they might not participate efficiently and conduct direct assessment through measuring tourists' intellectual processes. Thus, this paper employs the Technology Acceptance Model (TAM) (Davis et al., 1989) to analyse social media advertising effects on Malaysian ecotourists based on the features of informativeness and service functionality. The outcomes of this work can deliver the ecotourism sector with a hypothetical study framework with the help of statistics that may also assist authorities to use social media advertising on suitable ecotourists more significantly.

\section{LITERATURE REVIEW}

Ecotourism is one of the sustainable forms of tourism enabling guests to experience and comprehend the region's ecology and biodiversity (Amanda, 2021). Duffy (2002), described ecotourism as a kind of enjoyment in the wildlife environment, whereas Ryan et al. (2000) differentiated it from being a systematic understanding of the inherent ecological cycle by adding that it is a focused view of nature and habitats. Thus, correlating with the natural world, recreational activities including community festivals are evaluated by ecotourism (Wight, 1996); though others define it as changing inputs and having a new pursuit (Weiler, 1993). Indeed, it is a travelling adventure that allows tourists to learn about the distinctive natural and societal atmosphere as well as preserving a better surrounding environment. Ecotourists are travellers who enjoy goods and activities relevant to ecotourism (Page and Dowling, 2002). Ryan et al. (2000) emphasized the concentration of communication with nature, while Wight (1997) notes that eco-travellers search for "uncrowded, remote, wilderness, learning about wildlife, nature, local cultures, and residential area welfare and physical challenge." Different experimental studies (Eagles, 1992; Fennell and Malloy, 1999) accomplish that ecotourists are keen to perceive skills as much as possible in a given period and demand moderate-quality packages and appropriate service execution. Hence, eco-travellers generally remark ecotourism related packages and travels based on their existing knowledge and also the influence of social media advertisements (Chen and Tsai, 2019).

Social networking also enables travel companies to develop and establish customer relationships, and thus boost their company and marketing strategy (Mir, 2012). Moreover, social networking also enables travel companies to develop and establish customer relationships, and thus boost their company marketing strategy through social media advertising (Mangold and Faulds, 2009). In this context, conventional advertisement platforms like "Television and Newspapers" become less useful compared with social networks advertising (Duffett, 2015). Businesses have increasingly capitalised in social media advertisements such as Twitter and Facebook to market their offerings (Barnes and Mattson, 2009). As described by eMarketer (2019), all-inclusive business in 2019 invested $\$ 333.25$ billion on social media advertisement for targeting customers globally, and by $2023, \$ 517.51$ billion is expected to hit 60.5 percent of global advertising expenditures. In the tourism sector, social media advertisement has greater importance as it notifies visitors about additional offers, tour packages, and other details easily and effortlessly (Ogucha et al., 2015)

Davis and his associates integrated the technology acceptance model (TAM) (Davis, 1989; Davis et al., 1989). TAM has been widely regarded as a comprehensive but influential framework in which scholars and informational experts can accurately describe usage intentions or acceptance behaviour (Yi and Hwang, 2003). TAM is probably the best-recognized enhancement in scholarly research to study the use and purpose of technological innovation (Karim et al., 2020). In order to extend this, the study of Venkatesh et al. (2003), the "Unified theory of acceptance of and use of technology" (UTAUT), includes eight constructs of technology acceptance framework. However, across many, the latest technological acceptability meta-analyses, perceive usefulness and perceive ease of use factors linger the two most reliable aspects of the technology acceptance model, which consist of UTAUT (King and He, 2006; Schepers and Wetzels, 2007; Yousafzai et al., 2007). The aim of using the framework is facilitating the effective execution of core elements. Over the last two decades, a considerable number of researches have concentrated mostly on the identification of frequent advertising media that affect the perceived user behaviour of technologies in tourism (Saxena and Khanna, 2013; Roult et al., 2016; Dao et al., 2014). This research explores external variables that influence perceived usefulness and perceived ease of use of social medial advertisement on ecotourism in Malaysia. The analysis examines that the effect of external factors on structures not only significantly contributes to the theoretical models but also makes a significant contribution to developing proper characteristics, such as informativeness of promotional content that may refer to upgraded user acceptance. At the social media, promotion execution in ecotourism has certainly become relevant (Odoom et al., 2017). The framework established on the technology acceptance model (TAM) (Davis et al., 1989) is shown in Figure 1 below, theories, and assumed relationships (encircled in the boxes). The figure illustrates these two external factors- informativeness and service functionality of social media advertisement in Malaysian ecotourism, which influence "perceived usefulness" and "perceived ease of use" and affect "behavioural intention to use" social media advertising. 


\section{Informativeness}

The function of ads to inform users of alternatives and specific content is known as the advertisement informativeness (Ducoffe, 1996). It helps users make "high value" product decisions (Rotzoll et al., 1996). One of the key reasons for utilizing social media ads is searching and swapping information (Muntinga et al., 2011). In this respect, ecotourists willingly search social media ads because its content is an appropriate means of making such a decision which offers comprehensive contacts display and additional product details that are displayed along with images and video presentation (Dao et al., 2014). In fact, advertisement knowledge is viral in nature (Saxena and Khanna, 2013). Indeed, details of service providers may be scanned, exchanged, or any interest of other visitors and followers of certain goods and services and feedback are displayed below the ads. Thus, social media advertising, which contains particularly ecotourism interrelated info, will affect "perceived ease of use" and "perceived usefulness" for ecotourists. Major tourism service providers now a days have integrated ecotourism with the internet to disseminate information related to ecotourism destinations (Das and Hussain, 2016; Sadiq and Adil, 2020). Tourists exhibit information-seeking behaviour, which enables service providers to tailor social media advertisement according to the needs of information seekers (Zhang et al., 2012; Ashraf et al., 2020). A number of clusters are formed on the social media to advertise when different sources of information bear importance to the tourists (Ahmad and Khan, 2017). Websites related to eco-tourism and social networking sites have been frequently used by the service providers to provide information related to the service packages (Sadiq and Adil, 2020). The present study, which focuses on the literature review, suggests the subsequent hypotheses:

$\mathbf{H}_{1}$ : Informativeness will have a positive effect on the perceived ease use of social media advertisement.

$\mathbf{H}_{2}$ : Informativeness content will have a positive effect on the perceived usefulness of social media advertisement.

\section{Service Functionality}

Potential tourists typically visit social media ads for at least two reasons, to seek information about a product or service or to buy a product or service (Odoom et al., 2017). Moreover, DeLone and McLean (2003), in the mid-1980s, service functionality itself acted two roles, as an information provider and a service provider. Therefore, this study describes service functionality as per the social media advertisements ability to provide relevant service when tourists need it. The service can be a transaction in which offerings assist ecotourism service or products such as adequate package details and buying facilities through social media (Armstrong and Hagel, 1996). The service might even help the accumulation and peruse of information to encourage and select the right option, provide modified connections or even resources as well as encourage search engine interaction with appropriate tour planning mechanism (Roult et al., 2016). As functionality supports to active site operation, there is a positive link between perceived ease of use and perceived usefulness level (Baloglu and Pekcan, 2006). Ho and Lee (2007) found that the service functionality has a significant potential impact on tourists "behavioural intention" towards social media advertisements. In the context of service functionality of social media advertisement in ecotourism refers to the availability of reliable, verified and high-quality information which has positive effect on perceived usefulness (Hernández et al., 2011, Sadiq and Adil, 2020). Ecotourism is a part of an experiential product (Oviedo-García et al., 2017), therefore, the quality of social media advertisement has an important role in influencing an individual's overall decisionmaking process. Researchers like Scherer et al. (2019) and Kim (2016) have extensively studied the link between service functionality and perceive ease of use on social media advertisement in ecotourism. They found that service providers prefer only those social media advertisements that offer quality service and information. Furthermore, Ashraf et al. (2020) and Mohammadi (2015) observed that service functionality has a has a positive influence on perceived usefulness and perceived ease of use. Cautious reflection on results described in the literature review led to the following hypotheses: The preceding hypotheses were given due to diligent consideration of the outcomes reported in the existing literature:

$\mathbf{H}_{3}$ : Functionality will have a positive effect on the perceived ease of use of social media advertisement.

$\mathbf{H}_{4}$ : Functionality will have a positive effect on the perceived usefulness of social media advertisement.

\section{Perceived Ease of Use}

The TAM proposal demonstrates that the behavioural intention to use (BITU) is a factor for the applied use of technology arrangements, and two precedent principles decide this behavioural intention to use (BITU): perceived usefulness (PU) and perceived ease of use (PEU) (Davis, 1989; Davis et al., 1989). Therefore, PEU is a determining factor of PU, as users find a technological procedure more useful if it has no annoyance and excessive exertion. In addition, other variables are considered as similar. Even though several scientists have indicated that perceived ease of use has to direct connection to perceived usefulness, the results of Ndubisi et al. (2001) initiate that "perceived ease of use" had no effect on "perceived usefulness" of technology. The term 'advertisement' is a finite source, which an individual allocates to utilize it while performing a number of activities, for instance, acceptance of new technology (Nuryyev et al., 2020) or exploring information over the social media (Cheng, 2012; Mohammadi, 2015). Previous studies reveal that perceived ease of use has a positive effect on individual's intention to use social media as their source of desired information hub (Mohammadi, 2015; Sadiq and Adil, 2020). Moreover, individuals also believe that use of technology reduces their effort (Filimonau and Naumova, 2020) and in turn leads them to adopt the latest technology (Sadiq and Adil, 2020). Further, the relationship between perceived ease of use and perceived usefulness has previously been established a number of times (Chen and Tsai, 2019; Islam, 2013; Mohammadi, 2015; Scherer et al., 2019) and it has been found that perceived ease of use positively influences perceived usefulness (Chen and Tseng, 2012; Cheng, 2012; Kwok and Koh, 2019). In addition, perceived ease of use is also found to have indirect effect on intention to use through perceived usefulness in eco-tourism context (Sadiq and Adil, 2020). Therefore, their research was performed on a consortium of female entrepreneurs in 2000 who were unaware or were not exposed to technology as they ran small 
businesses. They did business on a daily basis instead of using technology to improve their performance. They also did not have to work with their daily initiatives to improve their efficiency using technology. The critical operator can typically be seen as perceived ease of use when technology is relatively new (Saxena and Khanna, 2013; Roult et al., 2016; Dao et al., 2014). Components used to measure PU, PEU, and BITU are shown in Figure 1. Proceeding the TAM framework. This research approved component interactions in the sense of social media ads further with the subsequent hypotheses:

$\mathbf{H}_{5}$ : Perceived ease of use will have a positive effect on the behavioural intention to use social media advertisement.

$\mathbf{H}_{\mathbf{6}}$ : Perceived ease of use will have a positive effect on the perceived usefulness of social media advertisements.

\section{Perceived Usefulness}

Perceived usefulness articulates the depth to which eco-travellers feel that utilising social media ads can assist them in their tourism involvement. Perceived usefulness is described as a step to which an entity believes that applying an intelligence system will prolong their output (Davis, 1989). In the TAM model, perceived usefulness hypothesises to foresee the direct relationship along with behavioural intention to use information systems (Park et al., 2014). Ecotourists focus on reducing the threat involved in travelling and because of that, they explore all available opportunities. They choose to use social media advertising only if they perceive it more beneficial. A study conducted by Muntinga et al., (2011) found "perceived usefulness" to have a significant and positive relationship with "behavioural intention to use" social media advertising as an electronic source of information. Dao et al. (2014) found perceived usefulness to have a major impact on "behavioural intention" to use social media advertisements. According to Mackenzie and Lutz (1989), in an extended TAM model, "perceived usefulness" is found to have the substantial and strongest effect on ecotourist. Mun and Hwang (2003) found a positive and significant relationship associated with perceived usefulness and behavioural intention. Davis (1989) defines perceived usefulness as 'the degree to which a person believes that using a specific system would be improving overall working performance'. This led eco- tourists to embrace the social media advertisement (Chen and Tsai, 2019; Sadiq and Adil, 2020; Ashraf et al., 2020). Extant literature suggests that perceived usefulness is a key predictor of intention to use social media advertisement, which motivates eco tourists to adopt user-friendly technology (Kim, 2016). Moreover, tourists' willingness to adopt technology depends upon their perception about its usage (Ashraf et al., 2020). Previous researchers have also found a positive influence of perceived usefulness on intention to use towards technology acceptance (Kim, 2016; Mohammadi, 2015; Kwok and Koh, 2019). Therefore, this highlights that if tourists have high perceived usefulness of the technology, the likelihood of having the intention to adopt technology to search information would be high (Nuryyev et al., 2020). Based on the above literature, the following hypothesis is proposed:

$\mathbf{H}_{7}$ : Perceived usefulness will have a positive effect on the behavioural intention to use.

\section{Conceptual Framework for this study}

Based on the above discussion and past literature, the following conceptual framework (Figure 1) has been developed for further hypothesis testing.

\section{METHODOLOGY}

\section{Construct Measurement}

The current framework of the research comprises five constructs namely, informativeness, service functionality, perceived ease of use, perceived usefulness and

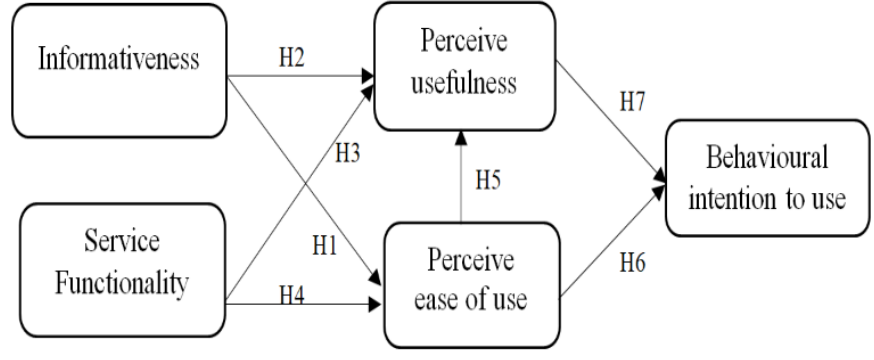

Figure 1 Conceptual framework behavioural intention to use where, informativeness, service functionality and perceived usefulness were represented by three items, perceived ease of use is illustrated by four items, and behavioural intention to use social media advertising is explained by five items. However, items of each construct were adapted mainly from (Lin, 2010). Items of each construct were then modified slightly to fit the current study. Five-Likert scale was used to measure the degree of agreeableness among the respondents (e.g., 1= strongly disagree to $5=$ strongly agree). Each item in the questions was prepared using the English language only."Pretesting" also known as pilot testing where this test aims to improve the quality of all the research instruments. Therefore, the functionality of each construct is properly verified (Bryman, 2008). Twenty-five sets of questionnaires $(N=25)$ were initially distributed to tourists who have been using social media advertising in order to have their comments and feedback.

\section{DATA COLLECTION}

Primary data for this study were collected using two methods. The first method involved using electronic medium (e.g., Google form, WhatsApp, and Facebook), while the second method involved direct interaction where questionnaires were passed in person. The researcher applied digital or on-line surveys mostly because it is easy to administer, lower cost, faster data collection and analysis, and is easy to eliminate missing data in survey responses (Hair et al., 2016). Secondary data for this study was collected from several past papers and previously conducted studies. A total of 466 data were collected from the Klang Valley area in Malaysia based on the total population reported at 1,991,068 tourists at the end of December 2019 (mytourismdata.tourism.gov.my). Out of the total population, 395 data were deemed appropriate for analysis. Next, 71 sets of data were discarded after the screening and cleaning processes were completed. However, the sample for the finite population is calculated based on the formula below: Based on formula, the number of samples that were needed for this study is at least 384 respondents, based on the total population reported in tourism data Malaysia, we have taken 395 as our sample size. 


$$
n=\frac{\frac{Z^{2} \times P \times(1-P)}{e^{2}}}{1+\frac{Z^{2} \times P(1-P)}{e^{2} N}} n=\frac{\frac{1.96^{2} \times 0.5 \times(1-0.5)}{0.05^{2}}}{1+\frac{1.96^{2} \times 0.5(1-0.5)}{0.05^{2} 1991068}} n=384
$$

Note: $\mathrm{N}$ denotes the population size, e denotes the margin of error, $\mathrm{z}$ indicates the $\mathrm{z}$-score, $\mathrm{P}$ indicates Population

\section{DATA ANALYSIS AND RESULT}

To analyze the demographic profile, SPSS version 21.0 was hired. To authenticate the dimensional model and structural prototype, this research employed Smart PLS software version 3.0.

\section{Demographic Profile}

Demographic data in Table 1 shows that males responded are more than females. $212(53.67 \%)$ of the respondents are males, and $183(46.33 \%)$ are females. The majority age is 26 to 30 years old (41.01\%), followed by the age range $18-25(32.41 \%)$. As for occupation, the majority of respondents are students $(42.78 \%)$, followed by $132(33.42 \%)$ who are in the private service, the government employees are 43 individuals (10.89\%), self-employed and others are $35(8.66 \%)$ and $16(4.05 \%)$ respondents respectively. Additionally, the majority of respondents' educational qualification is the bachelor's degree (45.82\%), followed by a master's (33.67\%). However, respondents are asked about their last time travel history, and it has been found that the majority have travelled six months ago (28.61\%), and respondents who travelled twelve months ago are $90(22.78 \%)$.

Table 1 Demographic Profile

\begin{tabular}{|c|c|c|c|}
\hline Measure & Items & Frequency & Percentage \\
\hline \multirow[t]{2}{*}{ Gender } & Male & 212 & 53.67 \\
\hline & Female & 183 & 46.33 \\
\hline \multirow[t]{4}{*}{ Age } & Below 18 & 27 & 6.84 \\
\hline & $18-25$ & 128 & 32.41 \\
\hline & $26-30$ & 162 & 41.01 \\
\hline & 31 and above & 78 & 19.74 \\
\hline \multirow[t]{5}{*}{ Occupation } & Student & 169 & 42.78 \\
\hline & Private service & 132 & 33.42 \\
\hline & Government employee & 43 & 10.89 \\
\hline & Self-employed & 35 & 8.86 \\
\hline & Others & 16 & 4.05 \\
\hline \multirow[t]{4}{*}{ Educational qualification } & Diploma & 66 & 16.71 \\
\hline & Bachelor & 181 & 45.82 \\
\hline & Masters & 133 & 33.67 \\
\hline & $\mathrm{PhD}$ & 15 & 3.80 \\
\hline \multirow[t]{5}{*}{ Traveled last time } & Within one month & 81 & 20.51 \\
\hline & Three months ago, & 70 & 17.72 \\
\hline & Six months ago, & 113 & 28.61 \\
\hline & Twelve months ago, & 90 & 22.78 \\
\hline & One year and above & 41 & 10.38 \\
\hline
\end{tabular}

Tables 2 Construct reliability and convergent validity

\begin{tabular}{|c|c|c|c|c|c|c|c|c|}
\hline & AVE & $\alpha$ & CR & BI & SF & INF & PEU & PU \\
\hline $\begin{array}{c}\text { Behavioral } \\
\text { Intention }\end{array}$ & 0.810 & 0.941 & 0.955 & $\mathbf{0 . 9 0 0}$ & & & & \\
\hline $\begin{array}{c}\text { Service } \\
\text { functionality }\end{array}$ & 0.897 & 0.942 & 0.963 & 0.684 & $\mathbf{0 . 9 4 7}$ & & & \\
\hline Informativenes & 0.898 & 0.943 & 0.963 & 0.679 & 0.705 & $\mathbf{0 . 9 4 8}$ & & \\
\hline $\begin{array}{c}\text { Perceived } \\
\text { ease of use }\end{array}$ & 0.827 & 0.930 & 0.950 & 0.725 & 0.630 & 0.653 & $\mathbf{0 . 9 1 0}$ & \\
\hline $\begin{array}{c}\text { Perceived } \\
\text { usefulness }\end{array}$ & 0.904 & 0.947 & 0.966 & 0.631 & 0.683 & 0.665 & 0.716 & $\mathbf{0 . 9 5 1}$ \\
\hline
\end{tabular}

*BI: Behavioural Intention, SF: Service functionality, INF: Informativeness, PEU: Perceived ease of use

PU: Perceived usefulness

\section{Measurement Model}

To evaluate the assessment framework convergent and discriminant validity, tests were conducted. For assessing the convergent validity of this study, values of composite reliability and Cronbach's alpha for each construct are suggested to be greater than or equal to 0.70 as per the recommendation of Chin (1998). Additionally,

values for the average variance extracted (AVE) are which confirms that the measurement model maintained sufficient convergent validity. To show discriminating legitimacy, the square root of the AVE of each construct should always be higher than the construct's correlation with other latent variables (Fornell and Larcker, 1981). In Table 2, the results are also reported demonstrating good discriminating validity of the measuring model. Besides, cross-loading of all items has been examined, and the result indicated that the loadings of each construct represent the higher value of each item within the constructs.

The distinctness of the construction is focused on discriminating the validity of the phenomenon taken by a construct that is unique and not the other constructs represented in the framework (Hair et al., 2013). Discriminant validity can be assessed using the Fornel-Larcker and Heterotrait Monotrait Ratio of correlations (HTMT) by assessing the cross-loaded accuracy of constructs. Initially, to accomplish discriminant validity, construction loadings shall be high on themselves and low on other constructs (Vinzi et al., 2010). Table 2 illustrates the decent discriminant validity as it illustrates that the square AVE of every factor is bigger than any of its correlations with the other factors.

\section{Analysis of Structural Model}

The structural model signifies the connection between the constructs or the latent variables which were theorized in this study (Matthews et al., 2016). Both path coefficients and $\mathrm{R}^{2}$ scores were established by the structural model analysis. According to Hair et al. (2017), $\mathrm{R}^{2}$ values of $0.75,0.50$, and 0.25 , which describe substantial, moderate, and weak levels of predictive accuracy. The t-value $>1.96$ is significant at $\mathrm{p}<0.05$ and t-value $>2.58$ is significant at $\mathrm{p}<0.01$ (Hair et al., 2017). Figure 2 shows that the $\mathrm{R}^{2}$ value in this model is $61.8 \%$ for PU, $48.3 \%$ for PEU, and $55.1 \%$ for BI. Figure 1 and Table 3 illustrate the path coefficient $(\beta), t$-statistics, and $p$-value of each hypothesis. Based on the analysis, all the hypotheses are found to be significant, except hypothesis $\mathrm{H}_{2}$, thus supported. $H_{l}(\beta=0.415, \mathrm{t}=4.165)$ indicates the path between informativeness and perceived ease of use of social media advertisement, indicating the positive and significant relationship among INF and PEU. $H_{2}(\beta=0.197$, $\mathrm{t}=1.478$ ) shows the path between informativeness and perceived usefulness found no significant and positive relationship 
between INF and PU of social media advertising. $H_{3}(\beta=0.337, \mathrm{t}=3.357)$ demonstrates the positive relationship between service functionality and perceived ease of use of social media advertising. $H_{4}(\beta=0.288, \mathrm{t}=2.153)$ explains that service functionality has a positive and significant influence on perceived usefulness. $H_{5}(\beta=0.405, \mathrm{t}=4.083)$ prescribed the significant and positive relationship between the perceived ease of use and the perceived usefulness. Furthermore, $H_{6}$ and $H_{7}$ found to be significant and positive, where $\mathrm{H}_{6}$ shows the $\beta$ value 0.560 and $\mathrm{t}$ value 6.561 , meaning that perceived ease of use has a significant positive influence on behavioral intention to use SMA which also measures the strongest influence on BI. Lastly, $H_{7}(\beta=0.230$, $\mathrm{t}=2.801)$ shows that a positive and significant correlation between perceived usefulness and behavioral intention is associated.

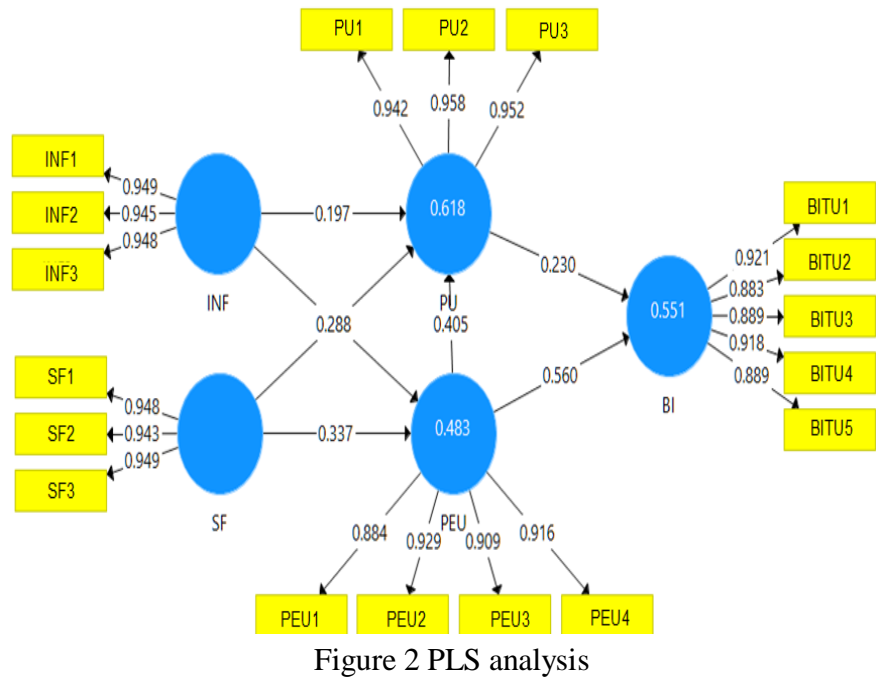

Table 3 Model Fit

\begin{tabular}{|l|l|l|}
\hline Fit Indices & Estimated Model & Ideal Threshold \\
\hline SRMR & 0.072 & $<0.08$ \\
\hline Chi-Square & 466.88 & Upper is better \\
\hline NFI & 0.901 & $>0.9$ \\
\hline
\end{tabular}

Table 4 Result of Hypotheses Testing

\begin{tabular}{|l|l|l|l|l|l|}
\hline Hypotheses & Relationship & $\boldsymbol{\beta}$ & t-Stats & P-Value & Decision \\
\hline $\mathrm{H}_{1}$ & $\mathrm{INF} \rightarrow \mathrm{PEU}$ & 0.415 & 4.165 & 0.000 & Supported \\
\hline $\mathrm{H}_{2}$ & $\mathrm{INF} \rightarrow \mathrm{PU}$ & 0.197 & 1.478 & 0.140 & Not Supported \\
\hline $\mathrm{H}_{3}$ & $\mathrm{SF} \rightarrow \mathrm{PEU}$ & 0.337 & 3.357 & 0.001 & Supported \\
\hline $\mathrm{H}_{4}$ & $\mathrm{SF} \rightarrow \mathrm{PU}$ & 0.288 & 2.153 & 0.031 & Supported \\
\hline $\mathrm{H}_{5}$ & $\mathrm{PEU} \rightarrow \mathrm{PU}$ & 0.405 & 4.083 & 0.000 & Supported \\
\hline $\mathrm{H}_{6}$ & PEU $\rightarrow \mathrm{BI}$ & 0.560 & 6.561 & 0.000 & Supported \\
\hline $\mathrm{H}_{7}$ & $\mathrm{PU} \rightarrow \mathrm{BI}$ & 0.230 & 2.801 & 0.005 & Supported \\
\hline
\end{tabular}

\section{FINDINGS}

Table 4 shows the outcome of hypothesis testing, which is also the empirical result based on data obtained for this study.

\section{DISCUSSION}

This study examined informativeness, service functionality, perceived ease of use, and perceived usefulness to find out whether it had an impact on behavioural intentions when people consider the content of social media ads to be useful. According to the findings, having an informative website greatly helps in a user's perception of how easy it is to use the information thus, (H1 was supported). Based on the analysis, the survey respondents felt that social media is a great source of knowledge to go back to when looking for tours. If this is the case, respondents believe that simple details on travel packages would be easy to find. With regards to whether it was useful or informative, the study concluded that there was no connection between that and usefulness ( $\mathrm{H} 2$ was not supported). Both service functionality and perceived usefulness were positively correlated with the number of hours a week customer used the current service (H3 and H4 were supported). It is in regard to how useful or relevant each user thinks a social network can be, and then relates this to how they plan to use it (H4 and H5 were supported). PEU was found to be significant for determining perceived usefulness and behavioural intention to use social media advertising $\left(\mathrm{H}_{4}\right.$ and $\mathrm{H}_{5}$ were supported). Among them, PEU signifies the strongest determinant in describing behavioural intention to use social media advertising, followed by PEU and PU (Karim et al., 2020). Lastly, perceived usefulness of social media advertising was found to have a positive influence on behavioural intention to use among ecotourists in Malaysia.

\section{CONCLUSION, LIMITATIONS AND FUTURE RESEARCH DIRECTIONS}

The intention of the study is to explore the context of publicity informativeness and the value of advertising and service functionality on ecotourism. For social media advertisement in ecotourism, a conceptual framework has been projected and empirically tested as well. The empirical findings indicate that a product or service for tourism is marketable when an informative advertisement on social media is utilized. This will foster an optimistic attitude toward social media advertising, which creates a positive tourists' response. Nonetheless, there are other drawbacks to this study. Firstly, the study was restricted to the Malaysian background, which could affect the widespread use of the data. Secondly, only certain Malaysian social media groups and fan pages on ecotourism and travel were selected as a sample in the questionnaire distribution. The construct validity of outcomes also could be enhanced by the inclusion of a wider range of social media groups or tourism fan pages. Thirdly, the analysis concentrated on the compilation of on-line data, e.g., Google Docs. Future studies may explore the physical aspect of physical data collection. More work can be carried out on other variables, which can also modify the approach in ecotourism to social media advertisements. To extend the proposed model in further studies, it may be necessary to combine some variables that influence the use of advertising in social media such as interactivity (Dao et al., 2014). Finally, studies in other tourism industries may also serve as a possible approach for future analysis for informativeness and service functionality in social media publicity responses.

\section{REFERENCES}

Ahmad, A., \& Khan, M.N. (2017). Student seeking health-related information over internet: An empirical study. Journal of Health Management, 19(2), 352-367. https://doi.org/10.1177/0972063417699720

Amanda, Y. (2021). Ecotourism: Opportunity for the tourism sector in Malaysia to revive. Business Today. https://www.businesstoday. com.my/2021/03/09/ecotourism-opportunity-for-the-tourism-sector-in-malaysia-to-revive/

Ashraf, M.S., Hou, F., Kim, W.G., Ahmad, W., \& Ashraf, R.U. (2020). Modeling tourists' visitingintentions toward ecofriendly destinations: Implications for sustainable tourism operators. Business Strategy and the Environment, 29(1), 54-71. https://doi.org/10.1002/bse.2350 
Baloglu, S., \& Pekcan, Y.A. (2006). The website design and Internet site marketing practices of upscale and luxury hotels in Turkey. Tourism management, 27(1), 171-176. https://doi.org/10.1016/j.tourman.2004.07.003

Barnes, N.G., \& Mattson, E. (2009). Social media in the 2009 Inc. 500: new tools and new trends. Journal of New Communication Research, 4 (2), 70-79. https://conference-board.org/publications/publicationdetail.cfm?publicationid=7086

Bolton, R.N., Parasuraman, A., Hoefnagels, A., Migchels, N., Kabadayi, S., Gruber, T., Loureiro, Y.K., \& Solnet, D. (2013). Understanding generation Y and their use of socialmedia: a review and research agenda. Journal of Service Management, 24(3), 245267. https://doi.org/10.1108/09564231311326987

Bryman, A. (2008). Social research methods fifth edition; 108 -123. Oxford: Oxford University Press . https://bit.ly/3evU5Al

Chen, C.C., \& Tsai, J.L. (2019). Determinants of behavioral intention to use the personalized location-based mobile tourism application: An empirical study by integrating TAM with ISSM. Future Generation Computer Systems, 96, 628-638. https://doi.org/10.1016/j.future.2017.02.028

Chen, H.R., \& Tseng, H.F. (2012). Factors that influence acceptance of web-based e-learning systems for the in-service education of junior high school teachers in Taiwan. Evaluation and Program Planning, 35(3), 398-406. https://doi.org/10.1016/j.evalprogplan.2011.11.007

Cheng, Y.M. (2012). Effects of quality antecedents on e-learning acceptance. Internet Research, 22(3), 361-390. https://doi.org/10.1108/10662241211235699

Chin, W.W. (1998). The partial least squares approach to structural equation modeling. Modern methods for business research, 295(2), $295-336$.

Chung, J.Y., \& Buhalis, D. (2008). Information needs in on-line social networks. Information Technology \& Tourism, 10(4), $267-281$. https://doi.org/10.3727/109830508788403123

Dao, W.V.T., Le, A.N.H., Cheng, J.M.S., \& Chen, D.C. (2014). Social media advertising value: the case of transitional economies in Southeast Asia. International Journal of Advertising, 33(2), 271-294. https://doi.org/10.2501/IJA-33-2-271-294

Das, D., \& Hussain, I. (2016). Does ecotourism affect economic welfare? Evidence from Kaziranga National Park, India. Journal of Ecotourism, 15(3), 241-260. https://doi.org/10.1080/14724049.2016.1192180

Davis, F.D. (1989). Perceived usefulness, perceived ease of use, and user acceptance of information technology. MIS quarterly, 13(3), 319-340. https://doi.org/10.2307/249008

Davis, F.D., Bagozzi, R.P., \& Warshaw, P.R. (1989). User acceptance of computer technology: a comparison of two theoretical models. Management science, 35(8), 982-1003. https://doi.org/10.1287/mnsc.35.8.982

Delone, W.H., \& McLean, E.R. (2003). The DeLone and McLean model of information systems success: a ten-year update. Journal of management information systems, 19(4), 9-30. https://doi.org/10.1080/07421222.2003.11045748

Ducoffe, R.H. (1996). Advertising Value and Advertising on the Web. Journal of Advertising Research, 36(5), 21.

Duffett, R.G. (2015). Facebook advertising's influence on intention-to-purchase and purchase amongst millennials. Internet Research, 25(4), 498-526. https://bit.ly/3vTgOMt

Duffy, R. (2002). A trip too far: ecotourism, politics, and exploitation. Earthscan, 98-127. https://eprints.soas.ac.uk/id/eprint/17771

Eagles, P.F. (1992). The travel motivations of Canadian ecotourists. Journal of Travel Research, 31(2), 3-7. https://doi.org/ $10.1177 / 004728759203100201$

El-Haddadeh, R., Weerakkody, V., \& Peng, J. (2012). Social networking services adoption in corporate communication: the case of China. Journal of Enterprise Information Management, 25(6), 559-575. https://doi.org/10.1108/17410391211272838

Fennell, D.A., \& Malloy, D.C. (1999). Measuring the ethical nature of tourism operators. Annals of Tourism Research, 26(4), 928-943.

Filimonau, V., \& Naumova, E. (2020). The blockchain technology and the scope of its application in hospitality operations. International Journal of Hospitality Management, 87, 102-383. https://doi.org/10.1016/j.ijhm.2019.102383

Fornell, C., \& Larcker, D.F. (1981). Evaluating structural equation models with unobservable variables and measurement error. Journal of marketing research, 18(1), 39-50. https://doi.org/10.1177/002224378101800104

Hagel, J., \& Armstrong, A.G. (1996). The real value of on-line communities. Harvard Business Review, 74(3), 134-141.

Matthews, L., Sarstedt, M., Hair, J.F., \& Ringle, C. (2016). Identifying and Treating Unobserved Heterogeneity with FIMIX-PLS: Part IMethod. European Business Review, 28(1), 63. https://doi.org/10.1108/EBR-09-2015-0094

Hair, J.F., Ringle, C.M., \& Sarstedt, M. (2013). Partial least squares structural equation modeling: Rigorous applications, better results and higher acceptance. Long range planning, 46(1-2), 1-12.

Hair, J., Black, W., Babin, B., Anderson, R., \& Tatham, R. (2010). Multivariate Data Analysis New Jersey: Pearson Prentice Hall. Alih bahasa: Soleh Rusyadi Maryam. Jilid, 2.

Hammock, L.A., \& Niczyporuk, J.M. (2017). U.S. Patent No. 9,830,612. Washington, DC: U.S. Patent and Trademark Office.

Hernández, B., Jiménez, J., \& José Martín, M. (2011). Age, gender and income: Do they really moderate online shopping behaviour? Online Information Review, 35(1), 113-133. https://doi.org/10.1108/14684521111113614

Ho, C.I., \& Lee, Y.L. (2007). The development of an e-travel service quality scale. Tourism management, 28(6), 1434-1449. https://doi.org/10.1002/jtr.2097

Islam, A.N. (2013). Investigating e-learning system usage outcomes in the university context. Computers \& Education, 69, 387-399. https://doi.org/10.1016/i.compedu.2013.07.037

Islam, A.N. (2013). Investigating e-learning system usage outcomes in the university context. Computers \& Education, 69, 387-399. https://doi.org/10.1016/j.compedu.2013.07.037

Jonassen, D., Howland, J., Moore, J., \& Marra, R. (2003). Learning to solve problems with Technology: A Constructive perspective. Merrill Hall, OH.

Karim, M.W., Haque, A., Ulfy, M.A., Hossain, M.A., \& Anis, M.Z. (2020). Factors Influencing the Use of E-wallet as a Payment Method among Malaysian Young Adults. Journal of International Business and Management, 3(2), 1-12. https://doi.org/10.37227/jibm-2020-2-21

Karim, M.W., Ulfy, M.A., \& Huda, M.N. (2020). Determining intention to use smartphone banking application among millennial cohort in Malaysia. International Journal of Management and Sustainability, 9(1), 43-53. https://doi.org/10.18488/journal.11.2020.91.43.53

Kim, J.S. (2016). An extended technology acceptance model in behavioral intention toward hotel tablet apps with moderating effects of gender and age. International Journal of Contemporary Hospitality Management, 28(8), 1535-1553. https://doi.org/10.1108/IJCHM-06-2015-0289

King, W.R., \& He, J. (2006). A meta-analysis of the technology acceptance model. Information \& management, 43(6), $740-755$. https://doi.org/10.1016/j.im.2006.05.003

Kwok, A.O., \& Koh, S.G. (2019). Is blockchain technology a watershed for tourism development? Current Issues in Tourism, 22(20), 2447-2452. https://doi.org/10.1080/13683500.2018.1513460

Lee, J., \& Hong, I.B. (2016). Predicting positive user responses to social media advertising: the roles of emotional appeal, informati veness, and creativity. International Journal of Information Management, 36(3), 360-373. https://doi.org/10.1016/j.ijinfomgt.2016.01.001

Leung, D., Law, R., van Hoof, H., \& Buhalis, D. (2013). Social media in tourism and hospitality: a literature review. Journal of Travel \& Tourism Marketing, 30(1-2), 3-22. https://doi.org/10.1080/10548408.2013.750919

Lian Chan, J.K., \& Baum, T. (2007). Ecotourists' perception of eco-tourism experience in lower Kinabatangan, Sabah, Malaysia. Journal of sustainable tourism, 15(5), 574-590. https://doi.org/10.2167/jost679.0

Lin, C.T. (2010). Examining e-travel sites: an empirical study in Taiwan. On-line Information Review, 34(2), $205-228$. https://doi.org/10.1108/14684521011036954 
MacKenzie, S.B., \& Lutz, R.J. (1989). An empirical examination of the structural antecedents of attitude toward the ad in an advertising pretesting context. Journal of marketing, 53(2), 48-65. https://doi.org/10.1177/002224298905300204

Mangold, W.G., \& Faulds, D.J. (2009). Social media: the new hybrid element of the promotion mix. Journal of Business Horizons, 52 (4), 357-365. https://doi.org/10.1016/j.bushor.2009.03.002

Mir, I.A. (2012). Consumer attitudinal insights about social media advertising: a South Asianperspective. The Romanian Economic Journal, 15 (45), 265-288.

Mohammadi, H. (2015). Investigating users' perspectives on e-learning: An integration of TAM and IS success model. Computers in human behavior, 45, 359-374. https://doi.org/10.1016/j.chb.2014.07.044

Mun, Y.Y., \& Hwang, Y. (2003). Predicting the Use of Web-based Information Systems: Self-efficacy, Enjoyment, Learning Goal Orientation, and the Technology Acceptance Model. International Journal of Human-Computer Studies, 59(4), 431-449. https://doi.org/10.1016/S1071-5819(03)00114-9

Muntinga, D.G., Moorman, M., \& Smit, E.G. (2011). Introducing COBRAs: Exploring motivations for brand-related social media use. International Journal of advertising, 30(1), 13-46. https://doi.org/10.2501/IJA-30-1-013-046

Ndubisi, N.O., Jantan, M., \& Richardson, S. (2001). Is the technology acceptance model valid for entrepreneurs? Model testing and examining usage determinants. Asian Academy of Management Journal, 6(2), 31-54.

Nuryyev, G., Wang, Y.P., Achyldurdyyeva, J., Jaw, B.S., Yeh, Y.S., Lin, H.T., \& Wu, L.F. (2020). Blockchain Technology Adoption Behavior and Sustainability of the Business in Tourism and Hospitality SMEs: An Empirical Study. Sustainability, 12(3), 1-21. https://doi.org/10.3390/su12031256

Odoom, R., Anning-Dorson, T., \& Acheampong, G. (2017). Antecedents of social media usage and performance benefits in small- and mediumsized enterprises (SMEs). Journal of Enterprise Information Management, 30(3), 383-399. https://doi.org/10.1108/JEIM-04-2016-0088

Ogucha, E.B., Riungu, G.K., Kiama, F.K., \& Mukolwe, E. (2015). The influence of homestay facilities on tourist satisfaction in the Lake Victoria Kenya Tourism Circuit. Journal of Ecotourism, 14(2-3), 278-287. https://doi.org/10.1080/14724049.2015.1105811

Oviedo-García, M.Á., Castellanos-Verdugo, M., Vega-Vázquez, M., \& Orgaz-Agüera, F. (2017). The Mediating roles of the overall perceived value of the ecotourism site and attitudes towards ecotourism in sustainability through the key relationship ecotourism knowledge-ecotourist Satisfaction. International Journal of Tourism Research, 19(2), 203-213. https://doi.org/10.1002/jtr.2097

Page, J.S., \& Dowling, R.K. (2002). Eco-tourism: themes in tourism. Essex: Pearson Education.

Park, N., Rhoads, M., Hou, J., \& Lee, K.M. (2014). Understanding the acceptance of teleconferencing systems among employees: An extension of the technology acceptance model. Computers in Human Behavior, 39, 118-127. https://doi.org/10.1016/j.chb.2014.05.048

Rotzoll, K.B., Haefner, J.E., \& Hall, S.R. (1996). Advertising in contemporary society: Perspectives toward understanding. University of Illinois Press.

Roult, R., Gaudette, M., Denis, A., \& Adjizian, J.M. (2016). Site management and use of social media by tourism businesses: the case of Quebec. Czech Journal of Tourism, 5 (1), 21-34. https://doi.org/10.1515/cjot-2016-0002

Ryan, C., Hughes, K., \& Chirgwin, S. (2000). The gaze, spectacle and eco-tourism. Annuals of Tourism Research 27 (1), $148-163$. https://doi.org/10.1016/S0160-7383(99)00061-4

Sadiq, M., \& Adil, M. (2020). Ecotourism related search for information over the internet: a technology acceptance model perspective. Journal of Ecotourism, 1-19. https://doi.org/10.1080/14724049.2020.1785480

Saxena, A., \& Khanna, U. (2013). Advertising on social network sites: a structural equation modelling approach. Vision, 17(1), 17-25. https://doi.org/10.1177/0972262912469560

Schepers, J., \& Wetzels, M. (2007). A meta-analysis of the technology acceptance model: Investigating subjective norm and moderation effects. Information \& management, 44(1), 90-103. https://doi.org/10.1016/j.im.2006.10.007

Scherer, R., Siddiq, F., \& Tondeur, J. (2019). The technology acceptance model (TAM): A meta-analytic structural equation modeling approach to explaining teachers' adoption of digital technology in education. Computers \& Education, 128, 13-35. https://doi.org/10.1016/j.compedu.2018.09.009

Taylor, P., Parker, K., Fry, R., Cohn, D., Wang, W., Velasco, G., \& Dockterman, D. (2011). Is college worth it? Pew Social and Demographic trends, 1-7. http://hdl.voced.edu.au/10707/3989

Thompson, B.S., Gillen, J., \& Friess, D.A. (2018). Challenging the principles of eco-tourism: insights from entrepreneurs on environmental and economic sustainability in Langkawi, Malaysia. Journal of Sustainable Tourism, 26(2), 257-276. https://doi.org/10.1080/09669582.2017.1343338

Tuten, T., \& Mintu-Wimsatt, A. (2018). Determining perceptions, attitudes and behaviour towards social network site advertising in a three-country context. Journal of Marketing Management 36 (5), 420-455. https://doi.org/10.1080/10696679.2018.1393277

Venkatesh, V., Morris, M., Davis, G., \& Davis, F. (2003). User acceptance of information technology: toward a unified view. MIS Quarterly, (27)3, 425-478. https://doi.org/10.2307/30036540

Vinzi, V.E., Trinchera, L., \& Amato, S. (2010). PLS Path Modeling: From Foundations to Recent Developments and Open Issues for Model Assessment and Improvement. In: Esposito Vinzi V., Chin W., Henseler J., Wang H. (eds) Handbook of Partial Least Squares. Springer Handbooks of Computational Statistics. Springer, Berlin, Heidelberg. https://doi.org/10.1007/978-3-540-32827-8_3

Weaver, D.B. (2001). Eco-tourism in the context of other tourism types. The encyclopaedia of eco-tourism, 73-83. https://cutt.ly/FbIYofj

Weiler, B. (1993). Nature-based tour operators: Are they environmentally friendly or are they faking it? Tourism Recreation Research 18 (1), 55-60. https://doi.org/10.1080/02508281.1993.11014665

Wight, P.A. (1996). North America eco-tourists: Market profiles and trips characteristics. Journal of Travel Research 24 (4), $2-10$. https://doi.org/10.1177/004728759603400401

Wight, P.A. (1997). Eco-tourism accommodation spectrum: Does supply match the demand? Tourism Management 18 (4), $209-220$ https://doi.org/10.1016/S0261-5177(97)00008-3

Yi, M.Y., \& Hwang, Y. (2003). Predicting the use of web-based information systems: self-efficacy, enjoyment, learning goal orientation, and the technology acceptance model. International Journal of Human-Computer Studies, 59(4), 431-49. https://doi.org/10.1016/S1071-5819(03)00114-9

Yousafzai, S.Y., Foxall, G.R., \& Pallister, J.G. (2007). Technology acceptance: a meta-analysis of the TAM: Part 1. Journal of Modelling in Management, 2 (3), 251-280. https://doi.org/10.1108/17465660710834453

Yusof, N.A., Abd Rahman, F., Che Jamil, M.F., \& Iranmanesh, M. (2014). Measuring the quality of eco-tourism services: Case studybased model validation. Sage Open, 4(2), 1-9. https://doi.org/10.1177/2158244014538270

Zhang, J., \& Mao, E. (2016). From on-line motivations to ad clicks and to behavioural intentions: an empirical study of consumer response to social media advertising. Psychology and Marketing, 33(3), 155-164. https://doi.org/10.1002/mar.20862

Zhang, L., Zhu, J., \& Liu, Q. (2012). A meta-analysis of mobile commerce adoption and the moderating effect of culture. Computers in Human Behavior, 28(5), 1902-1911. https://doi.org/10.1016/j.chb.2012.05.008

*** eMarketer (2019). Global Digital Ad Spending 2019. (E. Jasmine, Editor) Retrieved March 8, 2019, from https://www.emarketer.com/content/global-digital-ad-spending-2019 